\title{
MENJAWAB KESENJANGAN TEORI DAN PRAKTIK: PEMBELAJARAN PEDAGOGIK CALON GURU MELALUI LESSON STUDY
}

\author{
Yuswa Istikomayanti ${ }^{1}$ \\ Mashuri $^{2}$ \\ ${ }^{1}$ Pendidikan Biologi, Fakultas Ilmu Pendidikan, Universitas Tribhuwana Tunggadewi \\ ${ }^{2}$ MTs Muhammadiyah 1 Malang \\ E-mail: ${ }^{1}$ yuswa.istikomayanti@unitri.ac.id
}

\begin{abstract}
Pedagogic skills are not obtained instantly by prospective teachers if they only study learning theories. The facts in the microteaching class, although they have understood constructivism theory, they find it difficulty to initiate constructive learning instruction. Through Lesson Study practice, collaboration between teachers and prospective teachers in lesson planning is expected to raise a focus on important points in each stage of learning (pedagogic skills). The comments of prospective teachers are recorded, analysis of field notes, and also see phase with reflection are documented. Student prospective teachers self-assessment data on planning, observation, and reflection skills as supporting as quantitative data. The result is that prospective teachers reach the very good category in compiling a lesson plan, while the aspects of skills to observe and reflect on learning are in the medium and low categories. The implications of pedagogic learning through lesson study are discussed in this article.
\end{abstract}

Kata Kunci :kolegialitas, lesson study, mahasiswa calon guru, rencana pembelajaran.

\section{PENDAHULUAN}

Proses belajar setiap individu akan membentuk perspektif pemikirannya. Perspektif pemikiran ini akan membentuk bagaimana seorang akan menekuni profesi yang diinginkannya. Contohnya jika seorang calon guru menerapkan teknik mengajarnya, sebagian besar akan dimulai dengan mempraktikkan cara mengajar gurunya dahulu. Pemberian paradigma konstruktivis kepada para mahasiswa calon guru telah banyak dilakukan melalui beberapa penelitian (Widjaja dkk., 2015) dan (Safitri dkk., 2020). Namun demikian, pengembangan cara mengajar guru yang konstruktif masih sangat penting untuk meningkatkan kompetensi profesional guru seperti hasil penelitian (Andina, 2018).

Menjadi guru tidak hanya melakukan transfer ilmu dan pengetahuan dari guru ke siswa. Namun mengajar adalah suatu proses kompleks meliputi proses pelibatan guru dalam membentuk pengetahuan baru siswa, membentuk makna dari pengetahuan tersebut, mencari kejelasan konsep, mengkritisi suatu fenomena, dan menentukan keputusan. Dalam proses tersebut guru memerlukan berbagai aspek keterampilan mengajar meliputi pengetahuan mengenai konten (Content knowledge) atau Subject Knowledge pendapat peneliti lain (Großschedl dkk., 2019) serta aspek pedagogik atau teknik mengajarnya (Pedagogical Knowledge). Dalam praktik di kelas aspek konsep dan pedagogik menyatu menjadi keterampilan mengajar atau di kenal PCK (Pedagogical Content Knowlegde). 


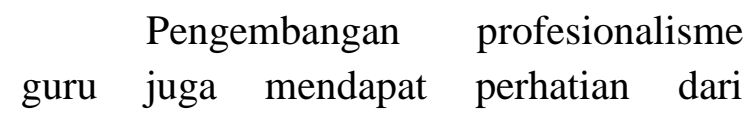
Kementerian Pendidikan dan Kebudayaan dengan dikajinya perubahan mekanisme pengembangan profesionalisme guru tahun 2020. Penekanan pada perbaikan mekanisme tersebut yaitu bahwa pengembangan profesionalisme guru agar lebih berdampak pada kualitas belajar siswa, lebih ringkas, bisa diukur dan dikembangkan, serta lebih adaptif terhadap perkembangan zaman. Hal ini didasarkan karena rendahnya pencapaian nilai ratarata kelulusan ujian kompetensi guru pada tahun 2015 dalam (Andina, 2018) yaitu untuk guru SD dengan kualifikasi banyak yang belum berkualifikasi S-1 dengan ratarata nilai 54,33, untuk jenjang SMP dengan rata-rata nilai 54,33 dan untuk jenjang SMA dengan rata-rata 61,71. Hasil tersebut merupakan rata-rata nasional, namun tentunya juga masih ditemukan kesenjangan kualifikasi guru pada beberapa daerah.

Latar belakang khusus yang menjadi titik tolak dari penelitian ini yaitu didasarkan hal yang sama dengan data penelitian (Andina, 2018), yaitu rendahnya kompetensi calon guru mahasiswa. Mahasiswa calon guru dalam subjek penelitian ini masih belum mahir dalam menyelenggarakan pembelajaran yang konstruktif dengan ciri yaitu kurangnya keterampilan berkomunikasi secara bertahap dengan siswa, sebagian besar dalam praktik mengajar mikro menggunakan metode konvensional yaitu ceramah satu arah, serta minim dalam inovasi pembelajaran Biologi, bahkan beberapa masih kurang percaya diri untuk berdiri di depan kelas mikro.

Beberapa hasil penelitian juga melaporkan perlunya peningkatan keterampilan mengajar pada mahasiswa calon guru (Gkioka, 2019) melaporkan pendidikan untuk calon guru fisika di Amerika Serikat belum secara langsung memberikan pengalaman mahasiswanya untuk mengelola laboratorium, serta minimnya pengalaman mahasiswa untuk menggunakan berbagai strategi mengajar sains dan strategi penilaian siswa. Hasil dari penelitian tersebut bahwa meskipun mahasiswa calon guru sudah memperoleh pengetahuan pedagogik mengenai strategi pembelajaran dan teknik penilaian.

Proses berfikir konstruktif yang diharapkan muncul pada siswa, tidak dengan mudah bisa dipraktikkan oleh sebagian besar calon guru. Proses belajar konstruktif terdiri dari empat bagian utama yaitu pembelajaran aktif, membangun, kumulatif, dan berorientasi pada tujuan. Aktif yaitu siswa melakukan kegiatan belajar tertentu untuk memproses informasi baru yang datang sehingga bisa mempelajari material dengan proses yang bermakna. Membangun atau konstruktif yaitu informasi baru tersebut perlu dielaborasikan dengan informasi lain sehingga siswa bisa memperoleh informasi sederhana untuk memahami adanya materi yang lebih kompleks. Kumulatif yaitu selama proses belajar siswa memperoleh pengalaman belajar dengan pemikirannya sehingga mampu membentuk pengetahuan barunya. Berorientasi pada tujuan yaitu siswa akan lebih sukses jika siswa memiliki orientasi atau tujuan belajarnya sendiri sesuai keinginnanya.

Tahap perencanaan pembelajaran menjadi penentu dalam keberhasilan pembelajaran yang diinginkan. Melalui tahapan perencanan dengan lesson design mahasiswa calon guru perlu memperkirakan bagaimana instruksi yang 
tepat untuk siswa. Instruksi ini bisa direncanakan sesuai dengan prediksi respon siswa yang beragam. Dengan demikian menurut (Widjaja dkk.., 2015; Buchard \& Martin, 2017; Ritter dkk.., 2020) keterampilan pedagogik perlu dilakukan secara bertahap dan dilakukan berulang-ulang. Hasil penelitian (Otero, 2004) menyatakan perlunya memberikan penguatan oleh instruktur terhadap hasil refleksi mengajar calon guru. Hal ini dikarenakan persepsi awal yang ada pada calon guru cenderung pesimis dari harapan keberhasilan mengajarnya. Calon guru yang mampu membangun instruksi untuk siswanya dengan lebih baik, adalah calon guru yang mampu melakukan inovasi terhadap cara mengajarnya.

Prinsip kolegialitas guru perlu dikembangkan di Indonesia. Masih sedikit penelitian yang mengkaji kolegialitas dalam aspek akademik atau pedagogik guru. Hasil penelitian (Istikomayanti, Yuswa; Lathifah A.S.; Mitasari Z., 2019) menyatakan kunci dari keberhasilan praktik lesson study pada sekolah adalah terciptanya kepercayaan kolega untuk saling membangun. Beberapa praktik lesson study di sekolah atau di tempat lain menjadi kurang membumi dikarenakan guru yang sudah memahami lesson study hanya memiliki satu atau dua kolega untuk membangun proses konstruktif pedagogik dan memperkaya wawasan keilmuan. Hal ini senada dengan penelitian (Buchard and Martin, 2017; Brew and Saunders, 2020; Ritter dkk.., 2020) untuk mempersiapkan calon guru sangat diperlukan kesempatan pengalaman belajar yang aktif dalam bentuk pembelajaran berbasis penelitian. Melalui pembelajaran berbasis penelitian pendidikan, mahasiswa calon guru akan melakukan kolaborasi dengan teman serta pembimbingnya. Dalam pembelajaran umum, mahasiswa tidak memperoleh kesempatan tersebut. Harapannya dengan sering melakukan pembelajaran berbasis penelitian pendidikan maka keterampilan merefleksi dan berinkuri akan terbangun sehingga mahasiswa bisa secara luwes mempraktikkan dalam kegiatan sehari-hari guru nantinya.

Penelitian ini menerapkan kolaborasi antara mahasiswa calon guru dengan guru yang telah memiliki pengalaman dan terampil dalam memoderasi perencanaan pembelajaran melalui lesson study. Proses kolaborasi antara mahasiswa calon guru memberikan dampak yang cukup besar jika dibandingkan kegiatan tanpa berkolaborasi. Mahasiswa calon guru secara konkrit memperoleh pengalaman mengembangkan kolegialitas misalnya dalam partisipasi menyusun pembelajaran, bersama-sama berinkuiri memperkirakan respon berfikir siswa, dengan seksama mendengar dan berdiskusi, serta wawasan berbagai media ajar yang bervariasi. Manfaat untuk guru yakni dengan berkolaborasi bersama mahasiswa calon guru akan memberikan pandangan baru, hal ini tidak terbatas lagi dengan masalah pengalaman mengajar. Lebih lanjut aspekaspek di dalam diri mahasiswa calon guru seperti kepercayaan diri, motivasi dan keteladanan menjadi seorang guru mulai muncul. Keterbatasan pada penelitian ini belum melaksanakan pengukuran PCK mahasiswa dalam penerapan praktik mengajar sebagai guru model. Fokus pada penelitian ini lebih banyak pada aspek perencanaan, pengamatan pembelajaran, dan refleksi pembelajaran sebagai observer dan tim dalam lesson study. 


\section{METODE}

Penelitian kualitatif ini dilakukan pada semester gasal 2018/2019 pada mata kuliah Penelitian Tindakan Kelas dan Lesson Study (PTK-LS) sebagai mata kuliah pilihan. Mahasiswa calon guru sebanyak 29 orang berada pada tahun ketiga ini baru memiliki pengalaman untuk mengobservasi pembelajaran yang dilakukan oleh sesama mahasiswa dalam pembelajaran mikro. Pada awal perkuliahan diberikan pemaparan teori dengan topik perencanaan dalam PTK, mengobservasi, dan melakukan refleksi, yang dipadukan dengan pengenalan tahapan kegiatan lesson study. Kegiatan lesson study dengan guru dilakukan sebanyak satu siklus terdiri dari tahapan perencanaan, pelaksanaan, dan refleksi. Mahasiswa telah memperoleh bekal secara teoritis untuk teknis pelaksanaan lesson study dan pembelajaran pada pertemuan kuliah. Kolaborasi diinsiasi oleh guru dan siswa yang sama-sama secara mutual membutuhkan kegiatan lesson study. Mahasiswa memerlukan guru dan siswa sebagai objek pengamatannya, sedangkan guru dan siswa membutuhkan pengamat yaitu mahasiswa calon guru untuk mengamati selama proses belajar.

Data kualitatif diperoleh selama kegiatan lesson study dijabarkan secara deskriptif dari komentar mahasiswa, catatan lapang selama kegiatan, dokumentasi kegiatan yang dianalisis oleh peneliti. Hal ini bertujuan untuk menjabarkan setiap teknik dalam lesson study memiliki dampak terhadap mahasiswa calon guru untuk mampu meniru cara mengembangkan profesi guru. Data kuantitatif aspek keterampilan merencanakan, keterampilan mengobservasi dan keterampilan merefleksi yang dilakukan sebelum dan sesudah kegiatan. Aspek-aspek dalam rubrik ini disusun dari berbagai sumber referensi Akiba dkk.., 2019; Arif Hidayat, 2019) untuk mengukur keterampilan pedagogik dan pengetahuan konten atau Pedagogical Content Knowledge (PCK). Hasil pencapaian skor sebelum dan sesudah dinanalisis dengan gain score $(N$ gain).

\section{HASIL}

Transfer Keterampilan Pedagogik dan Pengetahuan Konten (Pedagogical Content Knowledge) Guru Melalui Lesson Study

Mahasiswa calon guru pada bidang Pendidikan Biologi terbantu dengan adanya kegiatan praktik kolaborasi dengan guru di sekolah. serta hasil lesson design pada Gambar 1. Pada materi Energi kelas VIII SMP, mahasiswa berkontribusi dalam perencanaan (plan), mengobservasi pembelajaran (do), serta merefleksi pembelajaran (see). Tahapan perumusan rencana tindakan diawali dari guru yang menyampaikan ada satu siswa di kelas tersebut sangat pasif. Siswa tersebut hanya tertarik pada pelajaran tertentu. Guru sementara menyimpulkan bahwa siswa tersebut sangat tertarik dengan kegiatan belajar dengan praktikum sedangkan jika hanya mendengar guru, dia akan terlihat tidakbersemangat bahkan mengabaikan guru. Selain itu guru memberikan tantangan kepada mahasiswa untuk memberikan pembelajaran IPA menjadi pembelajaran yang menyenangkan dan kooperatif. Sesuai dengan materi pelajaran yaitu topik Energi pada sub topik pengenalan jenis-jenis Energi, mahasiswa 
Pendidikan Biologi dipacu untuk berfikir kritis dan inovatif, bagaimana memulai pembelajaran tersebut agar menarik, serta memperkirakan konsep dalam IPA meskipun dari bidang Pendidikan Biologi.

Guru sebagai moderator kegiatan perencanaan pembelajaran memulai dengan menuliskan topik materi pertemuan, membuat garis yang membagi kertas lesson design menjadi tiga bagian yaitu bagian inti, tengah dan akhir pembelajaran. Bagian tersebut tertulis pada Gambar 1. "Bertenaga" (awal pembelajaran), "Ayo Bermain" (inti pembelajaran) dan "Jelajah Alam" (akhir pembelajaran). Penamaanini diberi setelah proses penyusunan langkah pembelajaran pada bagian dalam kotak selesai. Selanjutnya guru mempersilahkan mahasiswa menyampaikan saran, hal apa yang perlu dikatakan guru untuk membuka pelajaran. Guru membandingkan saran tersebut dengan teknik "bagaimana jika". memberikan peluang kepada mahasiswa lain untuk mempertimbangkan "kalimat pembuka terbaik" mana yang sesuai untuk membuka pembelajaran. Kalimat pembuka ini tidak sekedar sapaan, tetapi mampu menggelitik siswa untuk mencari tahu, bisa dengan menceritakan hal yang memunculkan pertanyaan, media gambar, dsb

Hal ini sangat berbeda dengan praktik mengajar mikro mahasiswa di semester sebelumnya yang cenderung membuka pelajaran dengan salam, kemudian menanyakan kabar siapa siswa yang tidak hadir, dan begitu seterusnya sehingga masih konvensional atau umum dilakukan. Namun, saat melakukan observasi, mahasiwa terlihat antusias untuk mengetahui proses belajar siswa seperti pada Gambar 2. Mahasiswa terlihat antusias apakah rencana pembelajaran yang direncanakan bisa sesuai dengan harapan dengan memberikan media ajar

Maksud dari "bagaimana jika" adalah guru

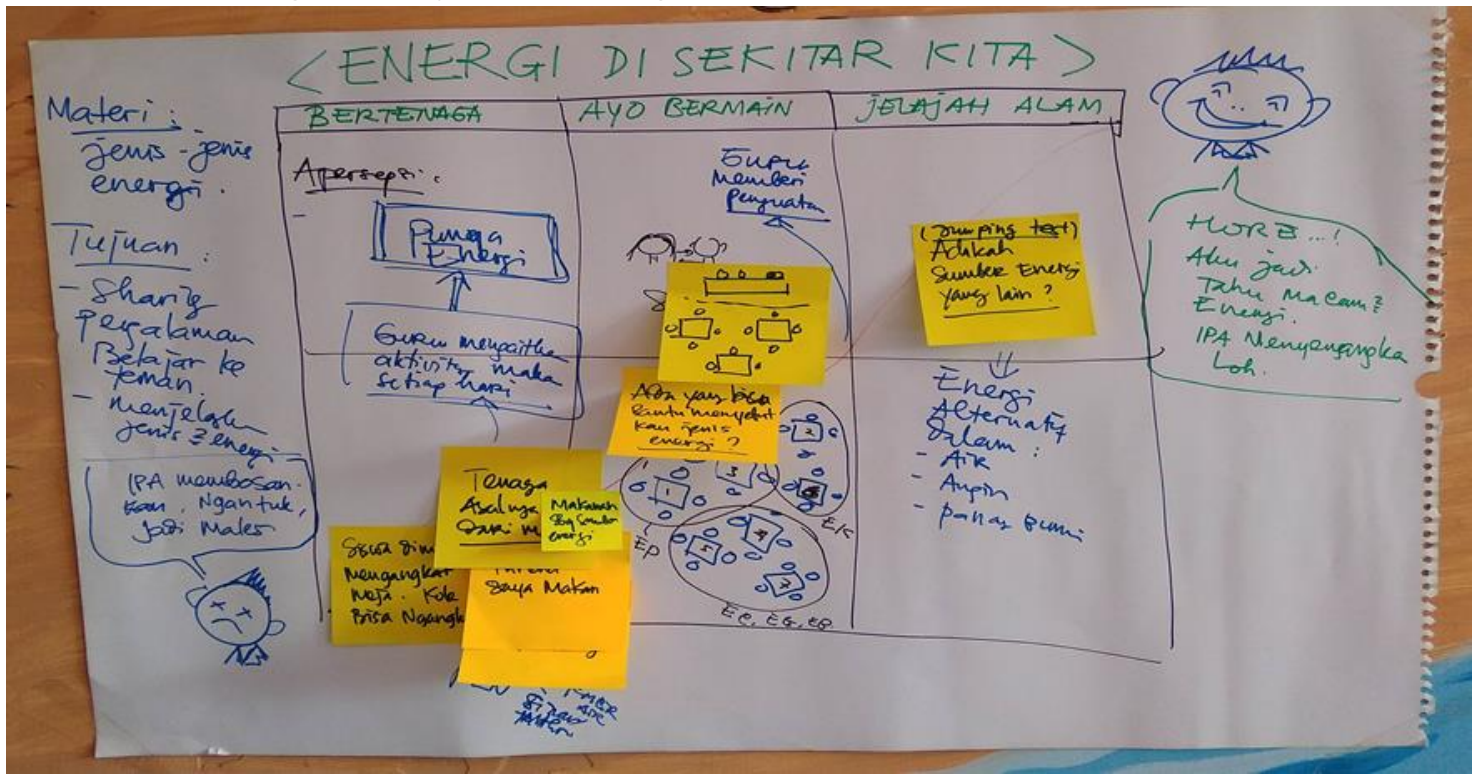

Gambar 1. Lesson design hasil kolaborasi guru kelas dan mahasiswa calon guru 


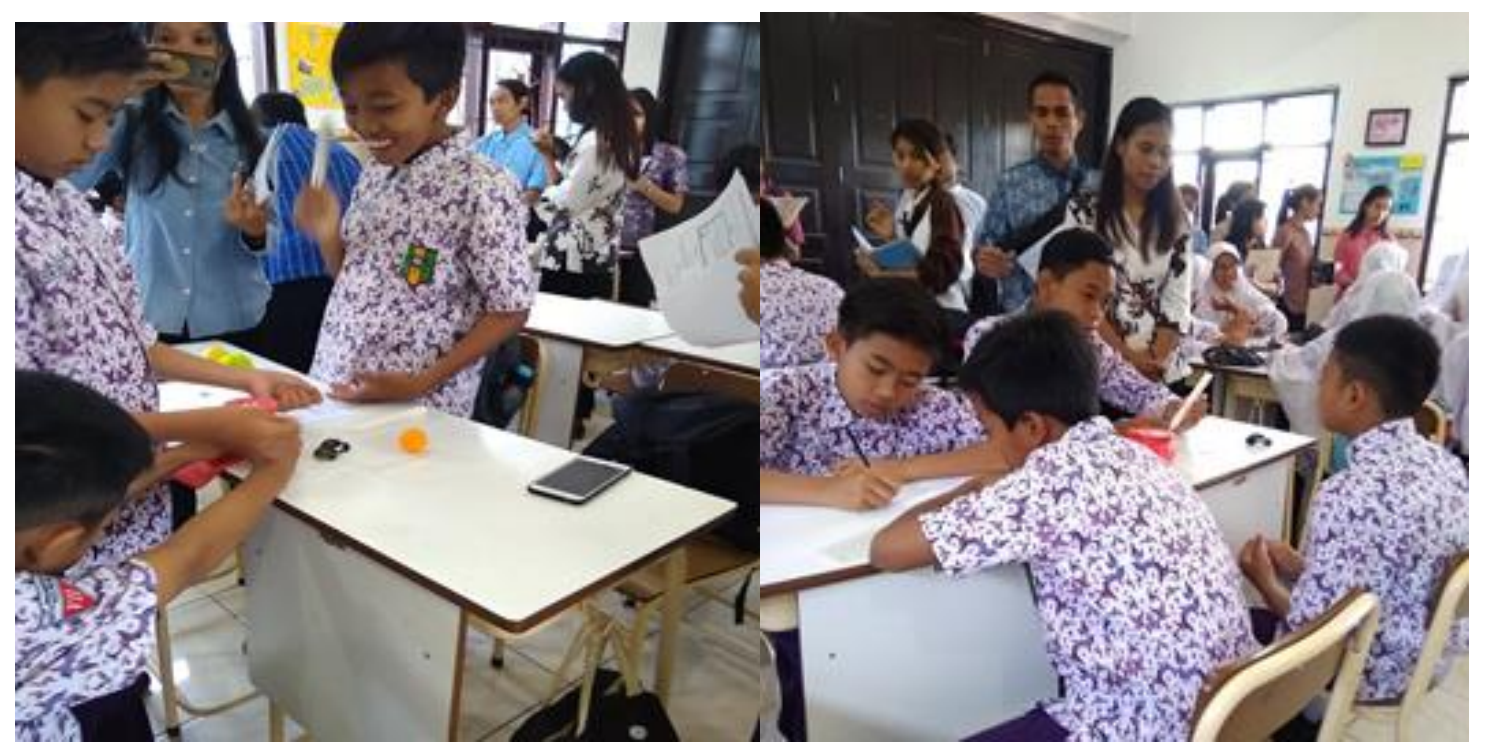

Gambar 2. Mahasiswa calon guru melakukan observasi lesson study

yang beragam. Hasil penelitian (Gubbels \& Vitiello, 2018)perlunya memberikan pembelajaran sains yang menyenangkan dan mengesankan untuk meningkatkan motivasi pelajar dalam sains yaitu dengan mengajak mahasiswa sains dan ilmuan menjadi guru mereka. Kesan belajar yang baik tersebut memberikan dampak pada identitas siswa mencintai sains, antusiasme belajar, penghargaan terhadap hasil sains, dan pemahaman proses sains.

Poin penting yang diperoleh dari kegiatan perencanaan yaitu pertama, mahasiswa bisa menyadari pentingnya menganalisis kondisi awal kelas dan memfokuskan tujuan perbaikan pembelajaran. Pada teori yang mereka peroleh saat kuliah tentunya hanya sebatas pemahaman bagaimana teknik menganalisis siswa yang terdiri dari aspek siswa, aspek guru, dan aspek media ajar. Sedangkan aspek interaksi antara siswa dan interaksi guru-siswa belum bisa mereka peroleh jika tidak dilakukan kegiatan kolaborasi dengan guru dan mengamati siswa secara langsung sebagai objek pengamatan. Kondisi motivasi siswa ternyata berperan penting dalam awal pembelajaran. Selain itu, guru tidak hanya bertanggung jawab untuk menyampaikan materi, tetapi bertanggung jawab untuk memfasilitasi semua siswa agar dapat belajar dengan baik.

Hal ini berdasar dari komentar salah satu mahasiswa pada sesi refleksi sebagai berikut:

“... Bapak (guru) sangat sabar saat menanggapi salah seorang siswa yang dari awal tidak bekerja (maksudnya tidak melakukan percobaan). Jika saya menjadi bapak, mungkin saya sudah marah atau emosi. Bapak bisa memberikan motivasi/pendekatan ke siswa tersebut, dan pada akhirnya ia mau mencoba untuk praktik bersama teman kelompoknya".

Poin selanjutnya mahasiswa mampu merumuskan tujuan perbaikan 
pembelajaran. Fokus perbaikan pembelajaran tersebut adalah meningkatkan aktivitas belajar siswa melalui pembelajaran kooperatif serta melalui media praktik bagaimana siswa bisa mengembangkan keterampilan proses sains mereka. Perumusan tujuan perbaikan pembelajaran tersebut awalnya sulit disusun oleh mahasiswa calon guru. Mereka belum bisa memahami secara nyata, aspek mana dalam pembelajaran yang perlu difokuskan. Melalui kegiatan lesson study berkolaborasi dengan guru, mahasiswa calon guru bisa memahami bahwa aktivitas belajar bisa dinilai dan terlihat secara nyata (visibel). Aspek-aspek ini tercantum dalam rubrik PCK dalam (Arif Hidayat, 2019) yaitu aspek pengetahuan pedagogik dengan rincian "bagaimana siswa belajar" yaitu guru menyusun rencana pengalaman siswa, dan merencanakan respon guru untuk berbagai respon siswa. Hal ini berdasar dari komentar mahasiswa A pada sesi refleksi sebagai berikut:

"Saat siswa X tidak kunjung melakukan instruksi Bapak (guru). Namun saat melihat teman-temannya asyik melakukan percobaan, akhirnya dia ikut mencoba apa yang dilakukan temannya"

Serta komentar guru dari refleksi tersebut sebagai berikut:

" Ya itu yang saya coba bangun, yaitu belajar dari sesama teman. Dimana siswa tidak selalu belajar dari guru. Saya memberikan lembar kerja yang berbeda dan topik percobaan yang berbeda di tiap kelompok. Meskipun tadi ada siswa yang tidak membawa perlengkapan, dan terlihat tidak tertarik di awal, namun saya mencoba mendekati dan akhirnya dia mulai melakukan percobaan"

Komentar mahasiswa B kembali saat refleksi:

"Iya betul Pak, pada salah satu kelompok yang kesulitan mencoba membuat balon udara dari tenaga panas lilin. Mereka terlihat tidak patah semangat. Mereka terus mencoba sampai akhir pelajaran, meskipun belum sempat melakukan pengambilan data. Namun, mereka bisa menyampaikan bahwa kegagalan percobaan dikarenakan faktor peralatan dan cara merakitnya belum baik. Namun mereka tetap berusaha. Bapak memberikan bantuan kepada setiap kelompok."

Komentar mahasiswa C selanjutnya saat sesi refleksi:

"Saya merasa pembelajaran yang Bapak berikan kepada siswa, sudah luar biasa sekali. Siswa disini bisa dibimbing untuk mandiri, mereka senang dan menikmati waktu selama belajar dengan bermain percobaan energi, dan bisa mempresentasikan ke depan. Hal ini berbeda dengan seperti yang saya perkirakan. Ternyata media belajar yang bervariasi tersebut sangat membantu proses belajar siswa, melakukan percobaan, dll." 
Tabel 1. Penilaian Diri Mahasiswa Terhadap Keterampilan Merencanakan, Mengobservasi dan Merefeleksi

\begin{tabular}{|c|c|c|c|c|c|}
\hline & Keterampilan Merencanakan & Pretest & Postest & $\begin{array}{l}\mathbf{N}- \\
\quad \mathbf{G} \\
\mathbf{a} \\
\mathbf{i} \\
\mathbf{n}\end{array}$ & Kategori \\
\hline 1 & $\begin{array}{l}\text { Menentukan jangkauan topik } \\
\text { pembelajaran sesuai tujuan } \\
\text { pembelajaran }\end{array}$ & 2,21 & 6,17 & 0,83 & Tinggi \\
\hline 2 & $\begin{array}{l}\text { Memperkirakan strategi, teknik dan } \\
\text { taktik bantuan guru untuk siswa }\end{array}$ & 2,10 & 5,66 & 0,73 & Tinggi \\
\hline 3 & $\begin{array}{l}\text { Menentukan media ajar sesuai } \\
\text { dengan kebutuhan belajar }\end{array}$ & 2,25 & 5,58 & 0,70 & Tinggi \\
\hline 4 & $\begin{array}{l}\text { Menentukan lompatan tugas } \\
\text { (jumping task) untuk siswa dari topik } \\
\text { pembelajaran }\end{array}$ & 2,38 & 5,62 & 0,70 & Tinggi \\
\hline & Keterampilan Mengobservasi & Pretest & Postest & $\begin{array}{l}\text { N- } \\
\quad \text { G } \\
\text { a } \\
\text { i } \\
\text { n }\end{array}$ & Kategori \\
\hline 1 & $\begin{array}{l}\text { Mengamati secara umum bagaimana } \\
\text { guru mengajar }\end{array}$ & 2,93 & 4,89 & 0,48 & Sedang \\
\hline 2 & $\begin{array}{l}\text { Mengamati interaksi siswa dengan } \\
\text { sumber belajar, serta interaksi siswa } \\
\text { dengan guru serta interaksi siswa } \\
\text { dengan siswa lainnya }\end{array}$ & 3,10 & 5,51 & 0,62 & Sedang \\
\hline \multirow[t]{2}{*}{3} & $\begin{array}{l}\text { Fokus pada pembelajaran siswa dan } \\
\text { mampu mendokumentasikan detil } \\
\text { proses belajar individu dan } \\
\text { kelompok }\end{array}$ & 2,24 & 5,17 & 0,61 & Sedang \\
\hline & Keterampilan Merefleksi & Pretest & Postest & $\begin{array}{l}\mathbf{N}- \\
\quad \mathbf{G} \\
\mathbf{a} \\
\mathbf{i} \\
\mathbf{n}\end{array}$ & Kategori \\
\hline 1 & $\begin{array}{l}\text { Menyampaikan pendapat dan saran } \\
\text { dari pengamatan secara umum }\end{array}$ & 2,93 & 4,90 & 0,48 & Sedang \\
\hline 2 & $\begin{array}{l}\text { Melakukan analisis dari hasil } \\
\text { pengamatan berdasarkan catatan } \\
\text { detil proses pembelajaran }\end{array}$ & 2,14 & 3,45 & 0,27 & Rendah \\
\hline 3 & $\begin{array}{l}\text { Menyampaikan analisis kritis proses } \\
\text { pembelajaran dan implikasinya }\end{array}$ & 2,38 & 3,41 & 0,22 & Rendah \\
\hline
\end{tabular}

Catatan: Rubrik penilaian ini dipadu dari berbagai sumber 
Komentar guru selanjutnya:

"Iya ini keberhasilan kita bersama

telah merencankan pembelajaran kemarin. Jadi, siswa disini memang perlu didekati.

Siswa X yang menjadi fokus perbaikan belajar saya tampaknya tadi cukup tertarik belajar sampai akhir. Memang perilaku siswa bermacam-macam."

Hasil transfer keterampilan PCK yaitu dijabarkan dalam keterampilan merencanakan tercapai dalam kategori sangat baik atau tinggi dengan kisaran skor 0,$70 ; 0,73$ dan 0,83 , keterampilan mengobservasi dalam kategori sedang dengan skor 0,$48 ; 0,61$; dan 0,62 , atau baik, sedangkan keterampilan merefleksi tercapai dengan kategori rendah dengan kisaran skor 0,22; 027, dan 0,48 berdasar pada Tabel 1. Bagaimana guru bisa meyakini bahwa seluruh siswa telah belajar pada pembelajaran yang diberikan? Hal ini mendapat perhatian dengan cara menyusun strategi pembelajaran dalam perencanaan, memperkirakan aktivitas guru saat siswa sedang berkelompok, memperkirakan aktivitas konstruktif siswa dengan memberikan langkah-langkah metode ilmiah yang tercantum dalam lembar kerja siswa. Poin-poin ini diperoleh mahasiswa melalui aktivitas perencanaan bersama guru. Guru sebagai moderator kegiatan perencanaan bisa membuka pemikiran mahasiswa untuk memperkirakan langkah-langkah yang akan dilakukan guru selama pembelajaran. Pada Tabel 1. Mahasiswa mencapai kategori sedang pada keterampilan mengobservasi. Mahasiswa melakukan observasi pada keterampilan proses sains meliputi siswa mempersiapkan alat dan bahan, tahap mengikuti prosedur kerja sesuai petunjuk kerja, tahap menyusun hipotesis, mengumpulkan data, dan menarik kesimpulan oleh siswa, serta penguatan guru. Namun, untuk melakukan analisis dan implikasi dari interaksi siswa dan guru serta siswa dengan lingkungan belajarnya, mahasiswa belum mencapai kompetensi tersebut.

Keterampilan untuk menentukan media ajar, metode pembelajaran, pengelolaan kelas dan keterampilan membelajarkan siswa dalam rubrik (Arif Hidayat, 2019) termasuk bagian dari keterampilan pedagogik (pedagogical content). Kesatuan aspek profesional meliputi keterampilan pedagogik (pedagogical content) dan pengetahuan konten (Content Knowledge). Keterampilan tersebut sulit diperoleh mahasiswa saat hanya belajar atau praktik mengajar dengan teman sesama mahasiswa saja. Namun, dengan terlibat dalam kegiatan lesson study bersama guru profesional, mahasiswa bisa secara konkrit memperoleh pengalaman tersebut dari pengamatan langsung. Saat guru akan memberikan umpan balik dari respon siswa, maka ada berbagai prediksi yang muncul dibenak pengamat. Setelah guru menyampaikan respon kepada siswa dan siswa kembali merespon, maka mahasiswa calon guru akan mengamati teknik tersebut sebagai strategi guru baik untuk menanggapi siswa, memotivasi siswa perorang, menjawab dalam kelompok, dan lain sebagainya (Brew \& Saunders, 2020).

Berdasarkan hasil refleksi yang dilakukan mahasiswa data dari Tabel 1. belum muncul keterampilan menganalisis pembelajaran lebih jauh pada tahap 
analisis kritis dan reflektif. Keterampilan merefleksi yang diberikan mahasiswa masih berada pada kategori refleksi deksriptif yaitu masih menceritakan hasil pengamatan dan belum memberikan penilaian terhadap perkiraan "bagaimana jika" aktivitas siswa yang diamati bisa menjadi "hal baru". Keterampilan merefleksi secara bertahap bisa dikembangkan oleh peserta dalam lesson study. Menurut beberapa penelitian dinyatakan keterampilan ini bisa dibangun melalui beberapa tahapan belajar. Tahap pertama yaitu dengan memfokuskan tujuan pembelajaran siswa yang ingin diamati. Tujuan belajar meliputi berbagai aspek baik akademik dan keterampilan hidup. Selanjutnya kolaborasi dengan praktisi pendidikan baik guru, atau fasilitator pendidikan tetap dibutuhkan untuk memberikan pandangan baru yang berbeda sehingga memperkaya kajian penelitian pembelajaran (Mynott, 2018; Akiba dkk.., 2019).

Beberapa mahasiswa namun ada yang memunculkan komentar refleksi bersifat analisis yaitu pada komentar mahasiswa $\mathrm{C}$ yaitu menyatakan dengan adanya media belajar bervariasi sangat membantu siswa untuk belajar mandiri dan bisa melakukan percobaan dan lainlain. Analisis ini muncul dari pandangan siswa yang baru pertama kali melakukan observasi dan refleksi. Hal ini merupakan potensi mahasiswa untuk dikembangkan. Mahasiswa calon guru sangat memerlukan kegiatan refleksi dan analisis dari objek langsung sehingga akan mempermudah pemahaman serta keterampilan belajar pedagogik (Gutierez, 2015). Kolaborasi dengan berbeda kompetensi dan latar belakang bahkan disiplin ilmu sangat disarankan (Ritter dkk.., 2020). Hasil penelitiannya menunjukkan kolaborasi dari dua orang dengan disiplin ilmu yang sama terlihat stagnan, sedangkan kolaborasi dengan orang berbeda disiplin menunjukkan kenaikan progres yang sangat signifikan.

\section{Implikasi Pembelajaran Pedagogik Calon Guru Melalui Lesson Study}

Pada proses pembelajaran pedagogik oleh guru kepada mahasiswa calon guru melalui sarana lesson study memberikan kesempatan kepada mahasiswa untuk memahami peranan sejawat atau kolegialitas. Meskipun dalam penerapan kali ini bertindak sebagai partisipan. Aspek kolegialitas (Madiha, 2015 dalam (Istikomayanti, dkk.., 2019)yang terbangun salah satunya pada aspek keterbukaan seorang guru untuk diobservasi pembelajarannya. Hal ini menjadi penting untuk diberikan kepada mahasiswa calon guru sebagai bentuk kepercayaan kepada kolega untuk saling mengisi kekurangan dan bersama-sama meningkatan kualitas pembelajaran yang dilakukan. Aspek dalam kolegialitas guru yaitu mampu saling mengajari satu sama lain dimana antara calon guru dan guru memberikan arahan, demonstrasi bagaimana model belajar yang digunakan, serta memberikan media ajar untuk bisa ditiru calon guru dalam pelaksanaan pembelajaran.

Menurut (Gutierez, 2015) peserta dalam lesson study tidak harus kolega tetapi bisa berasal dari partisipan, dan juga kolaborator untuk memberikan umpan balik dari kegiatan perencanaan dan refleksi pembelajaran. Poin penting untuk membangun pengembangan profesional guru melalui diskusi ilmiah ini yaitu guru bisa mengasah keterampilan 
refleksi pembelajaran. Sedangkan pada penelitian ini mahasiswa guru masih berada pada taraf rendah dan sedang pada Tabel 1. Mahasiswa masih menilai diri mereka bahwa masih mengamati pembelajaran secara umum dan menyimpulkannya. Beberapa mahasiswa sudah mendokumentasikan secara detil proses belajar pada individu dan kelompok siswa. Implikasi refleksi pembelajaran kolaboratif perlu menjadi pertimbangan. Menurut penelitian menyatakan dengan melihat kembali proses belajar siswa maka akan diperoleh pandangan yang berbeda dari guru-guru, tim guru tersebut akan mendapat temuan baru teknik instruksi mereka, serta akan memunculkan konsensus poin-poin untuk perbaikan pembelajaran mereka. Selain kolaboratif, refleksi diri guru secara pribadi dengan tertulis juga bisa menjadi bentuk kontemplasi proses belajar diri sepanjang hayat (Gutierez, 2015).

Pengukuran aspek keterampilan merencanakan, keterampilan mengobservasi dan keterampilan merefleksi yang dilakukan oleh mahasiswa calon guru berada dalam tahap inisiasi. Keterbatasan penelitian ini baru mengukur aspek pedagogik taraf inisiasi dikarenakan keterbatasan subjek penelitian yang belum mampu pada kompetensi yang lebih jauh serta kuantitas serta lamanya waktu melakukan kolaborasi dalam lesson study belum cukup banyak. Namun demikian, tahap inisiasi ini sebagai langkah awal untuk lebih mengembangkan aspek-aspek pedagogik calon guru dan juga guru. Karena fakta di lapangan (Andina, 2018) meskipun sudah profesi guru, aspek-aspek pedagogik dan pengetahuan konten
(PCK) oleh guru juga masih perlu dikembangkan.

Pada Tabel 1. Menunjukkan keterampilan perencanaan mahasiswa tercapai dengan baik namun keterampilan merefleksi baru pada tahap sedang dan rendah serta keterampilan mengobservasi pada tahap sedang. Keterampilan merefleksi adalah keterampilan kunci dalam peningkatan kualitas pembelajaran. Pada mahasiswa calon guru, keterampilan tersebut perlu dikembangkan dengan melakukan pembelajaran teknik observasi, refleksi pembelajaran dan mempraktikkannya berkali-kali. Begitu pula untuk praktisi lesson study, menurut (Gutierez, 2015) area refleksi terbagi dua bagian yaitu refleksi pada saat perencanaan pembelajaran, serta refleksi pembelajaran yang baru dilakukan. Hasil penelitiannya menunjukkan sebagian besar pengamat yang baru pertama kali melakukan observasi di kelas melakukan refleksi tipe deskriptif yaitu menjabarkan pandangan umum misalnya "siswa menikmati pembelajaran dari awal sampai akhir" dan juga "siswa memulai pekerjaan dengan terlambat karena mereka tidak memahami instruksi di lembar kerja". Hal ini terjadi pada mahasiswa calon guru pada penelitian ini. Sebagian besar pengamat awal masih belum mendalami titik-titik yang menjadi fokus proses belajar.

Selanjutnya menurut (Gutierez, 2015) Sebesar 30-40\% pengamat yang sudah fokus berada pada tahap refleksi analisis yaitu mampu mengenali dan peka dengan adanya dinamika yang kompleks di dalam kelas. Penyampaian analisis berupa bagaimana efek stimulus-respon serta umpan balik dari guru ke siswa, serta hubungan interaksi antara siswa, dan 
pola-pola komunikasi siswa. Pengamat analisis juga menyadari seberapa besar gap atau kesenjangan yang terjadi dalam pembelajaran. Misalnya "Saya belajar bahwa dengan perencanaan kolaboratif ini membuat kita menjadi guru yang lebih efektif. Meskipun masing-masing dari kita bisa menambahkan aktivitas sesuai dengan metode masing-masing dan kondisi siswa". Lebih fokus pada tujuan kolaborasi guru, pada tahap refleksi kritis dimana setiap guru atau kolaborator yang terlibat dalam tim lesson study bisa saling menyampaikan poin pandangannya apakah tujuan pembelajaran ini tercapai serta relevansi dari kegiatan tersebut.

Selain pengamat aatu observer sebagai partisipan dan atau juga kolaborator, yang menjadi kunci dalam jalannya diskusi refleksi yaitu peranan dari fasilitator. Fasilitator adalah seorang pakar yang memiliki pengetahuan mendalam mengenai pembelajaran. Namun demikian, tidak hanya pengetahuan tentang pembelajaran lebih penting menurut (Mynott, 2018; Akiba dkk.., 2019) yaitu fasilitator sebagai penggerak diskusi yang merupakan elemen penting. Pada penelitia ini Bapak Mashuri telah berhasil menjadi fasilitator yang baik untuk mahasiswa calon guru hingga menyelesaikan lesson design dengan baik. Fasilitator bisa seorang kolaborator misalnya bukan guru tetapi praktisi pendidikan seperti yang dilakukan Rio Suzuki sebagai fasilitator Lesson Study di beberapa sekolah di Indonesia melakukan pendampingan pelaksanaan Lesson Study dalam laporan penelitian (Rahayu, T. dan Nugroho, 2019) Jika sebuah sekolah telah memiliki fasilitator lesson study maka ia bertindak sebagai pembangun diskusi antara komponen siswa, materi serta kegiatan praktis guru. Fasilitator bisa membaur dengan membangun disonansi kritis antara satu pendapat guru dengan pendapat guru lain hingga terbentuk pemilihan teknis yang disepakati. Tentunya hal ini terbilang tidak mudah. Banyak terjadi kegagalan keberlanjutan dalam lesson study yang diinisiasi pada sebuah sekolah tetapi begitu fasilitator berganti maka kegiatan tersebut tidak berjalan lancar.

Menurut Mynott (2018) diperlukan waktu yang cukup untuk melakukan analisis pembelajaran. Fase yang dilakukan sebelum melakukan siklus lesson study yaitu dengan melakukan kajian pustaka atau membaca, mulai merencanakan, dan praktik melatih kegiatan lesson study. Setelah melalui 1-3 siklus dilanjutkan dengan melakukan analisis. Seperti yang dilakukan pada guru dan juga fasilitator dalam kegiatan ini adalah dengan membuka proses berfikir partsipan dengan kalimat "bagaimana jika" selanjutnya dibandingkan dengan saran dari partisipan lain dan seterusnya. Hal ini telah berhasil menjadikan mahasiswa belajar bagaimana teknik memediasi, serta hal yang perlu dihindari adalah memberikan penilaian singkat dari pendapat partisipan. Tentunya keberhasilan diskusi panjang kritis ini tidak secara instan terjadi. Namun, dengan memperbanyak praktik mahasiswa calon guru untuk melakukan diskusi analisis kritis mengenai pembelajaran, serta membaca artikel pembelajaran, maka akan semakin menajamkan pemahaman pedagogik dan juga keterampilan pedagogik mereka.

\section{KESIMPULAN}


Kesimpulan dari penelitian ini dengan melakukan kolaborasi mahasiswa dengan guru sebagai fasilitator dan juga guru model memberikan kesempatan kepada mereka untuk melihat langsung dan terlibat dalam perencanaan pembelajaran yang dihasilkan dari proses inkuiri tim. Melalui kegiatan lesson study atau pembelajaran berbasis penelitian ini, mahasiswa berkolaborasi dan memperoleh keterampilan merencanakandengan kategori tinggi $(\mathrm{N}$ Gain: 0,70; 0,73 dan 0,83) keterampilan mengobservasi dengan kategori sedang (N Gain: 0,48; 0,61; dan 0,62), dan keterampilan merefleksi dengan kategori sedang dan rendah (N Gain: 0,22; 027, dan 0,48) meskipun masih pada tahap inisiasi. Namun dari hasil komentar mahasiswa dapat disimpulkan pengalaman kolaborasi ini merupakan pengalaman yang berkesan terhadap proses pembelajaran dan lebih lanjut kesempatan mahasiswa calon guru untuk berkolaborasi dan praktik lebih banyak diharapkan akan meningkatkan keterampilan pedagogik dan juga pengetahuan konten dan pedagogik (PCK) mereka.

\section{SARAN}

Saran penelitian selanjutnya yaitu diperlukan rencana pembelajaran penelitian lebih terstruktur dan terencana sehingga calon guru bisa melatih keterampilan refleksi diri serta keterampilan berinkuiri secara kolaboratif. Pembelajaran pedagogik juga melibatkan kemampuan dalam aspek penggunaan teknologi atau Technological Pedagogical Content Knowledge (TPACK).

\section{DAFTAR RUJUKAN}

Akiba, M., Murata, A., Howard, C. C., \& Wilkinson, B. (2019). Lesson study design features for supporting collaborative teacher learning. Teaching and Teacher Education, 77(April), 352-365, 1-15. https://doi.org/10.1016/j.tate.2018.10 .012

Andina, E. (2018). Efektivitas Pengukuran Kompetensi Guru. Aspirasi: Jurnal Masalah-Masalah Sosial, 9(2), 204-220. https://doi.org/10.46807/aspirasi.v9i 2.1103

Arif Hidayat. (2019). Developing and Validating A Technological Pedagogical Content Kknowledge (TPACK) Instrument For Secondary Pysics Preservice Teachers In Indonesia. Unnes Science Education Journal, 8(1), 31-40.

Brew, A., \& Saunders, C. (2020). Making sense of research-based learning in teacher education. Teaching and Teacher Education, 87, 102935, 111.

https://doi.org/10.1016/j.tate.2019.10 2935

Buchard, J., \& Martin, D. 2017. Lesson

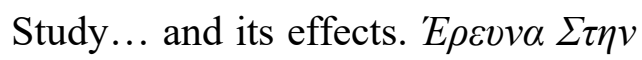

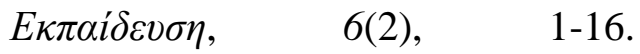
https://doi.org/10.12681/hjre.14809

Gkioka, O. 2019. Preparing pre-service secondary physics teachers to teach in the physics laboratory: Results from a three-year research project. AIP Conference Proceedings, 2075(1), 180009, 1-9. https://doi.org/10.1063/1.5091406

Großschedl, J., Welter, V., \& Harms, U. 2019. A new instrument for measuring pre-service biology 
teachers' pedagogical content knowledge: The PCK-IBI. Journal of Research in Science Teaching, 56(4), 402-439.

https://doi.org/10.1002/tea.21482

Gubbels, J. A. A., \& Vitiello, S. P. 2018. Creating and Teaching Science Lessons in $\mathrm{K}-12$ Schools Increases Undergraduate Students' Science Identity $\uparrow$. Journal of Microbiology \& Biology Education, 19(3), 1-9. https://doi.org/10.1128/jmbe.v19i3.1 594

Gutierez, S. B. 2015. Sally Guiterez. Teachers' reflective practice in lesson study A tool for improving instructional.pdf. 61(3), 314-328.

Istikomayanti, Yuswa; Lathifah A.S.; Mitasari Z. 2019. Collegiality as a Key for Improving Students Success in Lesson Study Practices. International Conference on Mathematics and Science Education, $3(1)$, 184-196. https://doi.org/10.1017/CBO978110 7415324.004

Mynott, J. P. 2018. Facilitating the Lesson Study Facilitator: a reflection on expertise in Lesson Study. IPDA Conference 2018, Border Crossings, November, 1-19.

Otero, V. K. 2004. “After I gave students their prior knowledge..." Pre-service teachers' conceptions of student prior knowledge. AIP Conference Proceedings, 720(1), 141-144. https://doi.org/10.1063/1.1807274

Rahayu, T. dan Nugroho, E. D. 2019., Endik Deni Nugroho. Borneo Journal of Biology Education, 1(1), 8-17.

Ritter, R., Wehner, A., Lohaus, G., \& Krämer, P. 2020. Effect of same- discipline compared to differentdiscipline collaboration on teacher trainees' attitudes towards inclusive education and their collaboration skills. Teaching and Teacher Education, $\quad 87, \quad 1-10$. https://doi.org/10.1016/j.tate.2019.10 2955

Safitri, M. A. D., Budiasih, E., \& Marfu'Ah, S. 2020. Mind mapping in argument-driven inquiry (ADI) model to improve students' critical thinking skills with a different prior knowledge in the topic of reaction rate. AIP Conference Proceedings, 2215(1), 020022, 1-9. https://doi.org/10.1063/5.0000755

Widjaja, W., Vale, C., Groves, S., \& Doig, B. 2015. Teachers' professional growth through engagement with lesson study. Journal of Mathematics Teacher Education, 20(4), 357-383. https://doi.org/10.1007/s10857-0159341-8 